Meta

Journal des traducteurs

Translators' Journal

\title{
Translation Activities in the Ottoman Empire
}

\section{Berrín Aksoy}

Volume 50, numéro 3, août 2005

Le prisme de l'histoire

The History Lens

URI : https://id.erudit.org/iderudit/011606ar

DOI : https://doi.org/10.7202/011606ar

Aller au sommaire du numéro

\section{Éditeur(s)}

Les Presses de l'Université de Montréal

\section{ISSN}

0026-0452 (imprimé)

1492-1421 (numérique)

Découvrir la revue

Citer cet article

Aksoy, B. (2005). Translation Activities in the Ottoman Empire. Meta, 50(3), 949-956. https://doi.org/10.7202/011606ar

\section{Résumé de l'article}

Dans l'Empire ottoman, l'activité traduisante n'a acquis sa véritable signification qu'à partir du $19^{\mathrm{e}}$ siècle. Du fait du régime islamique et de la structure sociale fermée de la société, l'Empire ottoman n’avait que peu de rapports avec l'Occident, ce qui explique que la traduction ait évolué de façon limitée et désorganisée, sans beaucoup d'influence sur l'activité culturelle et littéraire de la société, si ce n'est l'écriture de la langue turque ottomane. Les textes les plus souvent traduits de l'arabe et du persan étaient interprétés ou traduits sous une forme abrégée et concernaient en grande partie les textes islamiques. La traduction des oeuvres d'art et de la culture occidentale n'est apparue qu'au $19^{\mathrm{e}}$ siècle avec la réforme et les efforts d'occidentalisation. Bien qu'il fut accordé beaucoup d'importance aux traductions littéraires, scientifiques et philosophiques à cette époque, l'activité traduisante ne gagne de l'ampleur qu'avec la fondation de la République au $20^{\mathrm{e}}$ siècle. 


\title{
Translation Activities in the Ottoman Empire
}

\author{
BERRÍN AKSOY \\ Hacettepe University, Ankara, Turkey \\ berrinaksoy@yahoo.com
}

\begin{abstract}
RÉSUMÉ
Dans l'Empire ottoman, l'activité traduisante n'a acquis sa véritable signification qu'à partir du $19^{\mathrm{e}}$ siècle. Du fait du régime islamique et de la structure sociale fermée de la société, l'Empire ottoman n'avait que peu de rapports avec l'Occident, ce qui explique que la traduction ait évolué de façon limitée et désorganisée, sans beaucoup d'influence sur l'activité culturelle et littéraire de la société, si ce n'est l'écriture de la langue turque ottomane. Les textes les plus souvent traduits de l'arabe et du persan étaient interprétés ou traduits sous une forme abrégée et concernaient en grande partie les textes islamiques. La traduction des œuvres d'art et de la culture occidentale n'est apparue qu'au $19^{\text {e }}$ siècle avec la réforme et les efforts d'occidentalisation. Bien qu'il fut accordé beaucoup d'importance aux traductions littéraires, scientifiques et philosophiques à cette époque, l'activité traduisante ne gagne de l'ampleur qu'avec la fondation de la République au $20^{\mathrm{e}}$ siècle.
\end{abstract}

\begin{abstract}
In the Ottomans, translation activities took place without much significance until the 18th century. Due to the dominance of religion and the closed society structure, mostly texts on Islamic civilization and arts from Arabic and Persian were translated in the form of commentaries, explanations and footnotes. The only contribution of translation then may be said to be the promotion of written Ottoman Turkish which was used in Anatolia as well as among the Court circles. With the beginning of Westernization efforts in the 18th and largely in the 19th centuries, translation activities gained momentum and proliferated in kind and quantity. A large amount of books from the West and the East in the fields of science, literature, arts, social sciences, etc. were translated during that time. Although these activities were disorganized and inconsistent, they still helped the development of similar sciences and Modern Turkish Literature which was to reach its peak in the Modern Turkish Republic established in the 20 th century.
\end{abstract}

\section{MOTS-CLÉS/KEYWORDS}

Ottoman Empire, translation activities, turkish literature, westernization, Modern Turkish Republic

In this article, we are concerned specifically with translation activities in the Ottoman Empire by depending on the sources on the Ottoman society and culture derived from historiographical data. In order to establish an objective account of translation activities during the Empire period as the basis of our investigation, academic and scholarly documents have been investigated. The complexities of cultural life and confrontations in the Ottomans as an integral part of knowledge transfer are reflected in philosophical and historiographical narrations which had a higher esteem than other social sciences in the Ottoman Empire. Hence, the documents that have been employed in the preparation of this article largely refer to either first hand manuscripts of the Ottoman historians or the historiographic writings in the early Turkish Republic. 
Consequently, the only way to be informed about the past in terms of situation and action is written texts. Historical facts are recorded in these texts which are formulated in a linguistic medium. The concept of text in this paper, both historical and historiographical texts, is regarded as a consistent whole which reflects outside reality as objectively as possible. Textuality and context of this article are closely connected with the limited historiographical data available on the subject of translation activities in the Ottoman Empire.

Translation activities in the Ottomans started with the establishment of the Ottoman Emirate in 1299 in Western Anatolia which was to turn into an Empire after the conquest of Istanbul in 1453. In the early years, interpreting was the main mode of translating and became institutionalized during the rule of Sultan Mehmed the Conqueror. Interpreters were employed by the Court for mainly diplomatic contacts in the palace and in the conquered provinces, as well as for military purposes. They had a privileged position in the Court and were mostly Greeks. It is stated that Georgios Amirutzes who was the Conqueror's interpreter was also supposed to brief some Greek works to the Sultan (Günyol 1985: 324).

While interpreting started and continued in an organized manner in the Ottoman Empire, the same cannot be said of the translation activities. The religious nature of the Ottoman State, the dominance of Islamic learning and civilization, and the introvert society structure was not an amenable climate for translation to flourish in all fields. The Ottoman society was of a closed nature and cut off from older civilizations (Ülken 1997: 308). Since social and cultural life was dominated mainly by religion, works belonging to Islamic civilization, Islamic mysticism, and Islamic logic were translated into Turkish from Arabic and Persian in large numbers. However, instead of translating the whole text, explanations, summaries, footnotes and interpretations were preferred. The purpose of summarizing or reorganizing the translations was to illuminate the public on religious affairs with what seemed necessary for the translator and for the religious sect he belonged to (İsen 2003: 142).

In the Ottoman Empire until the 17th century, neither Greek or Latin works, nor the great scientific, intellectual or literary works of the Arab and Persian civilizations were translated. Intellectual activity was limited to scholastic training in Medreses (a form of a College or University) where civil servants of the religious state were educated according to religious discipline (Ülken 1997: 308). Hence, the cultural life of the Ottoman Empire was in a state of inertia since it was cut off from any kind of contact with foreign civilizations and culture. Contacts of any kind were maintained with the West only in terms of diplomatic and military fields which were limited to Court and army members and high-rank officials.

All throughout the Ottoman period, translation activities were carried out in a rather disorganized manner and translations were made only as personal initiatives. Hence, they apparently had no impact on the cultural, intellectual or the scientific life of the Empire until mid 19th century and the early 20th century. However, the translations were influential among Anatolian religious sects which is one reason why the translators took care to use a simple and clear language which could easily be understood by the common people. So, these translations at least served the creation of a written Ottoman Turkish which could be understood by the people outside the court circles (Yavuz 1983 qtd. in İsen 2003: 143). The simple style and syntax of the language of the translations was a reflection that Ottoman Turkish was still in the 
process of developing under the influence of Arabic and Persian, and especially the grammar used in the Qur'an. The loan words of Arabic and Persian origins in the translations were used by the common people in their religious terminology. According to some linguists and historians, in the translations even Turkish words were spelled differently in the same text. There was a certain amount of chaos in style and grammar use in the translations due to the fact that the translators did not have a prestigious model of written language before them to follow (Demirciogrlu 2003: 17, Levend 1974: 81, Toska 1996: 262-63, İsen 2003: 142).

Consequently, first initiatives to create an organized Turkish language were taken by Sultan Chelebi Mehmed (1413-1421) himself in the 15th century as part of his efforts to bring together Anatolian Emirates under the rule of the Ottoman State as the only political entity in the region.

Following Chelebi Mehmed, Sultan Murad II paved the way in the 15th century for establishing Turkish as the state language. Although a complete political union was yet to be achieved in Anatolia, the infrastructure institutions for arts, science and literature were beginning to emerge under the patronage of Sultan Murad II. The Sultan who was keen on having Turkish used in all social and state affairs officially imposed Turkish to be used in translations and other written activities. As a matter of fact, this may be a first example of state intervention in cultural affairs in the Ottomans. It is said that the Sultan issued a decree for all translators and interpreters all over the Empire to use a simple and refined Turkish in their works (Yavuz 1983: 15 qtd. in İsen 2003: 143).

The 15th century is also the time when classical Turkish Literature was enriched through the translations made from Iran and Central Asia. These translations were in the form of summaries and adaptations and served as models for similar works to be created in Turkish. For example, Feridun Attar's Tercüme-i Tezkiretü'l-evliyâ translated from Persian is the first example of the biography of holy persons' lives which was to become very popular in Anatolia in the later years. The scholars who mainly studied Islamic arts and civilizations were going to Egypt, Iran and Iraq to study the examples of Arabic and Persian works, particularly in the fields of medicine, literature (limited to some forms of poetry and letter-writing), Islamic arts and history.

The social structure and political developments in the Ottoman State in the 15th century created a need to record history. After the conquest of Istanbul, the society gained a consciousness of turning into an Empire. Hence, the need to record all kinds of social, economic and cultural activities in an organized written form became important. As a result, Tevârih-i Âl-i Osman (history of the sons of Osman) recordings began to be written down following the history recording models in Arabic and Persian cultures under the influence of translations from these languages. In the first examples of these history texts, the language is simple, fluent and full of Turkish structures and grammar use. However, as the genre developed, language turned into long and complicated sentences, with lots of figures of speech such as alliteration, similes and metaphors, artistic descriptions, imitations, etc. similar to the language used in Arabic and Persian texts.

The development of Turkish written language into what would be classical Ottoman narrative language may well be said to have happened under the influence of translations and adaptations made from Arabic and Persian languages in the fields of history and Islamic mysticism. The effect of the translations of poetic and narrative 
texts from Arabic and Persian contributed to the formation of the early period of Western Turkish as well as the creation of similar works in the Ottomans. For example, Sinan Pasha's translation of Attar's Tezkiretü'l-evliyâ and his own work which deals with religious and moral issues, called Maârif-nâme exhibit a lyrical language use and rich Turkish literary language which are said to be the first best use of literary Turkish (Tulum 2001, qtd. in İsen 2003: 147).

Until the end of the 15th century in military and scientific fields, translations were made from Arabic and Persian as summaries and adaptations. Cerrâhiyye-i İlhâniyye translated by Sabuncuoğlu Şerefeddin, and Müfredât-ı İbn Baytar translated by Halimî-i Amasyavî may be given as examples for these few translations. Although these activities did not help to promote the development of similar sciences in the Empire, they at least served to improve Ottoman Turkish which used Turkish words for the narration of ordinary and daily events and the use of Arabic and Persian vocabulary and formations for scientific and artistic descriptions (İsen 2003: 150). The inverted sentences and some connections and compounds are said to have entered into Turkish from Persian through the influence of the translations made in the 15th century (Cemiloğlu qtd. in İsen 2003: 149).

Apart from such limited activities, there were very few initiatives, and which proved fruitless, to translate great works of literature, philosophy, social sciences, etc. from Arabic and Persian works. Nor was there any transference of western works into Ottoman Turkish through these two languages. As a result, while the Renaissance was beginning to emerge in the West through the translations of classical works of antiquity, the all-powerful Ottoman Empire did not have the opportunity for a revival in cultural and scientific fields, as well as intellectually, hence the gradual decline of its power in the next centuries. Although translations until the 15th, 16th and 17th centuries at least served in the development of a written Ottoman Turkish language, they were not however widespread, consistent and organized. As a result, translation activities in the Empire were not influential enough to create the conditions for the full development of science and arts in the Ottoman Empire. Apart from the inconsistency of the translation activities, one of the reasons for the underdevelopment of science and the arts in the Empire may be the fact that the Ottoman society was mainly under the dominance of religion with an introverted structure which did not allow for contacts with other cultures and civilizations except in military and diplomatic fields (Ülken 1997: 308, Gürsel 1985: 320-323, Günyol 1985: 324-330).

Towards the 17th century, political, technical and economic reasons urged the Ottoman State to reevaluate its stance in the world as a world power, and to restructure the entire state mechanism for the survival of its power and integrity throughout all its territories in the West and the East. Consequently, Westernization efforts started long before the Reformation period (19th century) which created a need for more translations on different topics including secular texts from the West.

During the 17th and 18th centuries a new turn was taken in translation activities in parallel with Westernization efforts. In the first half of the 17th century Ebû Bekir Efendi, a geography scholar who had converted to Islam, translated Atlas Minor into Turkish and paved the way for the creation of Kâtip Chelebi's Cihannüma which was translated into western languages as Géographie. Cihannüma is a turning point in the production of scientific works in the Ottomans since the book was a kind of a review and survey of western sources such as Abraham Ortellius's (1527-1598) Teatrum 
Orbis Terraum, Mercator's (1517-1594) Atlas Major and Atlas Minor (Güven 1990: 116) Ömer Şifâ Efendi translated Pralikios's Tıbb-ı Cedid-i Kimyevî from Italian which was one of the first medical books from the West to be translated.

Since intellectual contacts with the West started and progressed in the 17th century, some translations from Turkish into western languages were also made. Kâtip Chelebi's Keşf-üz-zûnün was translated into Latin and later into German by Flügel, and Hacı Pasha's Teshil-i Şifâ was translated into German by Hans Barth (Ülken 1997: 319).

Apart from a few personal initiatives, the first organized translation activity started in the Tulip Age in the 18th century. A translation Council was formed under the directive of the Minister Ibrahim Pasha who had some great Persian and Arabic works, dictionaries, and science books translated into vernacular Turkish. This council opened the doors for the Greek works as well. Yanyal Esat Efendi translated Aristoteles's Physika into Turkish as Kitab-üs-Semaniye. According to Vedat Günyol, the intellectual interest in Greek civilization and the great works of antiquity in a way started with this translation (1985: 325).

The 17th and 18th centuries are important periods for translation activities in the Ottoman Empire. Contacts with the West proliferated as transference of western works consisted of topics such as geography, medicine, pharmacy, etc. while philosophy, literature and many social sciences were still not touched. Asim Efendi, another important translator, translated Necdüddin Firuz Âbadîs famous Kamus as Okyanus into vernacular Turkish loaded with Turkish words and idioms taken from the Anatolian public tongue in the 18th century (Ülken 1997: 321).

Reformation in the Ottoman Empire took place in the 19th century which also gave its name to the whole period. Under political, social and military pressures, efforts for Westernization in all fields of life and sciences took place for the purpose of opening up to other cultures and civilizations. The Empire which was gradually losing its power and territories in Europe, Africa and Asia was in a need to import scientific, technical and cultural innovations in order to compete with the other emerging powers in the world. The need to get to know the roots of western civilization led to an interest in western works of art, sciences, philosophy and literature. Along with an increase in the translation of technical and scientific works of the West, an increase was also seen in the translation of literary and philosophical works of the East. These translations enabled the development and enrichment of Turkish language to be able to produce similar works in Turkish such as Seyyid Ali Pasha's (1846) Kut $\hat{u}-i$ Mahrutât and Müneccimbaşı Muslihiddîn's Risâle-i ceyb-i muceyyeb-i âfâki which are about astronomy and geography (Fazlığlu 2003: 156-159).

Due to a growing interest in translation activities in the 19th century, translations from western works of art and literature also gained speed. However, these translations were not consistent and organized, and the dominant mode of language was still the heavy and ornamented court style of Ottoman Turkish. Most of the translations were either shortened, changed or left incomplete.

In order to overcome the disorganization in the translation activities, the Translation Chamber was established in 1832 to train translators who would carry out official correspondence, make translations, as well as teach French, as part of westernization efforts. The Translation Chamber is an important institution in the cultural life of the Ottoman Empire since it became "an atmosphere of a new world view 
flourishing with a new political ideal" (Tanpınar qtd. in Günyol 1985: 325). Many of the famous translators of the 19th century had the opportunity to have contacts with the western works of literature, philosophy and science through the French taught in the Chamber by the Greek, Italian and Jewish subjects of the Ottoman Empire. Hence, first contacts with French thought and literature took place by means of the activities of the Chamber which led to the formation of Reformation Literature from Court Literature and most importantly, to the creation of a Turkish for artistic and literary purposes (Berkes qtd. in Günyol 1985: 325).

An inclination toward western artistic and philosophical works was led by Sultan Abdulhamid's economics tutor Münif Pasha (1830-1910) who was also a translator. He translated from Voltaire and Fontenelle, and was followed by Yusuf Kâmil Pasha who translated Fénelon's Télémaque (1862) and Ziya Pasha who translated Molière's Tartuffe and J. J. Rousseau's Emile and Şinasi who translated La Fontaine, Florian, Racine and Lamartine, in prose and poetry, into Turkish.

The second half of the 19th century deserves attention with its intensified efforts of Westernization along with the proliferation in the kind and amount of translations. Until the second half of the 19th century, a reconciliation of eastern and western influences could be worked out among the intellectuals. The Ottoman society relied on the East for religious and moral issues, and on the West for science and technology. Gradually, as contacts with the West increased, a duality took place in the intellectual activities (Güven 1990: 119). More and more intellectuals wanted to have more contacts with the West and to be able to have more access to the western and classical works of art, as well as adopt a western life view and style (Ülken 1997: 326, Gürsel 1985: 327).

The establishment of a printing house enabled the publication of translations in larger numbers which could be circulated in the newly opened schools and Academies for Engineering, Medicine, Diplomatic and Administrative Sciences, etc. Ishak Hoca, Rıfkı Efendi, Emin Pasha were among the teachers of the Engineering Schools during the later years of the 19th century who also made translations from French and English which contributed to the development of positive sciences in the Empire. The advances in positive sciences helped for the creation of an intellectual medium where an increasing number of Ottoman intellectuals had contacts with the West and took an interest in creating similar works in Turkish. Consequently, the Constitution period which took place in the second half of the 19th century after the Reformation marked the revival of translation activities. To name a few, Raif Necdet Bey translated Tolstoy's Anna Karenina, translations of history and philosophy gained importance and Ahmet Refik Bey translated Seignobos's History of Civilization, Ali Reşat Bey translated many books on the French Revolution, Abdullah Cevdet translated some of Shakespeare's tragedies from English. Many books on philosophy, psychology, logic, social and political sciences were also translated mainly from French, English and German.

The increase in the amount and kind of translations however still went on in an inconsistent manner. There was not an established approach to the manner of translation and translation itself was not regarded as a science. Language studies were limited to foreign language learning and Turkish and unfortunately most of the translations were guided by the translator's own instincts and experiences without a consistent framework. Nevertheless, in spite of all these hindrances, translation activities in 
the 19th century lit the fire for future developments which eventually resulted in the creation of Modern Turkish Literature in the early years of the Turkish Republic in the 20th century.

It is worth mentioning that despite the shortcomings of the translation activities in the Ottoman Empire due to the reasons discussed briefly in this paper, new frames of mind, ways of thinking, and life styles as well as new literary genres such as the novel, drama, etc. and language use were introduced to Modern Turkish Literature through the translations of western works especially in the 19th century and early 20th century along with social and cultural improvements in the Ottoman society.

Consequently, although translation activities in the Ottoman Empire could not compete with similar activities in the West or elsewhere which resulted in the formation of the European Enlightenment, these activities laid down the foundation for the creation of sciences, literature and the arts as well as many cultural advancements to happen in the Modern Turkish Republic. Turkey was able to emerge from the introverted and religious state of the Ottomans to become a secular and modern social structure where today's progress in the intellectual, scientific and cultural fields could prosper within the background of an atmosphere which owes so much to translation activities in the Ottoman Empire.

As a conclusion, the intention of this paper is to present an assessment of the translation activities in the Ottomans while mainly depending on the available historiographical narrations as objectively as possible within the context of the present. However, the greater scope of making an assessment on any kind of activity of the past periods depending on historiographical data requires further research to be carried out within the context of the relation between history, history narration and historiography. This will eventually enable the researcher to have better and more comprehensive access to the actuality of the conditions of the past context and to evaluate and draw conclusions in a new light.

\section{REFERENCES}

Berkes, N. (1985): as qtd. in Günyol, Vedat (1985), “Türkiye'de Çeviri,” Cumhuriyet Dönemi Türkiye Ansiklopedisi, İletişim Yayınları, no. 11, p. 324-330.

DemircioǦLu, C. (2003): “19. Yüzyll Sonu Türk Edebiyatında Tercüme Kavramı" as quoted in İsen, Mustafa (2003), Dil, Kültür ve Çağdaşlaşma, Ankara, p. 137-151.

FAZlıoǦLu, İ. (2003): “Osmanlı Döneminde Fen Bilimlerindeki Türkçe Telif ve Tercüme Eserlerin Dil Bilincinin Oluşmasındaki Yeri ve Önemi” in Yediyıldız, Bahaeddin (ed.), Dil, Kültür ve Çağdaşlaşma, Ankara, p. 153-164.

Günyol, V. (1985): “Türkiye'de Çeviri,” Cumhuriyet Dönemi Türkiye Ansiklopedisi, İletişim Yayınları, no. 11, p. 324-330.

Gürsel, N. (1985): "Uygarlık ve Çeviri," Cumhuriyet Dönemi Türkiye Ansiklopedisi, İletișim Yayınları, no. 11, p. 320-323.

Güven, G. (1990): “Hilmi Ziya Ülken'in İslam Medeniyetinde Tercümeler ve Tesirler'i III,” Metis Çeviri, no. 13, p. 113-120.

İsen, M. (2003): “Türkçe’nin Yazı Dili Oluşumunda Çevirinin Rolü” in Yediyıldız, Bahaeddin (ed.), Dil, Kültür ve Çağdaşlaşma, Ankara, p. 137-151.

Levend, A. S. (1984): Türk Edebiyatı Tarihi in İsen, Mustafa (2003) Dil, Kültür ve Çağdaşlaşma, Ankara, p. 137-151.

Tanpinar, A. H. (1985): as qtd. in Günyol, Vedat (1985) Cumhuriyet Dönemi Türkiye Ansiklopedisi İletişim Yayınları, no. 11, p. 324-330. 
Toska, Z. (1996): “Ferideddin-i Attar’ın Mantıku’t-tayrı'nın 14. 16. 17. 20. Yüzyıllarda Yapılmış Türkçe Yeniden Yazımları" as qtd. in İsen, Mustafa (2003) Dil, Kültür ve Çağdaşlaşma, Ankara, p. 137-151.

Ülken, H. Z. (1997): Uyanış Devirlerinde Tercümenin Rolü, Ülken Yayınları, Istanbul.

Yavuz, K. (1983): as qtd. in İsen, Mustafa (2003) Dil, Kültür ve Çağdaşlaşma, Ankara, p. 137-151. 